\title{
Arctic Trophy Hunters, Tourism and Masculinities, 1827-1914
}

\author{
Lena Aarekol \\ The Polar Museum, Tromsø University Museum, UIT The Arctic University of Norway, \\ Tromsø Norway.
}

Trophy hunting in the Arctic happened in an intersection between tourism, expeditions and hunting. This study contributes to a discrete history of masculinity within the context of trophy hunting organized from North Norway and to a broader understanding of Arctic masculinity in general. As trophy hunting expeditions are primarily a male, even masculinist, tourist practice, an analysis from a gender perspective is unavoidable. By taking an empirical approach I investigate different performances of masculinity in written accounts of Arctic trophy-hunting expeditions from the period 1827-1914. The use of masculinity as a pivot demonstrates that a modification of the prevailing perception of Arctic masculinity is necessary. While the general understanding is dominated by an emphasis on physical strength, roughness, ingenuity, restless energy and strong will to self-realization, qualities connected to the traditional values and knowledge of trappers, sailors and explorers, my analysis shows that trophy hunting introduced aristocratic ideals such as gentlemen's sport, selfdiscipline, hunting morals, care for nature and distribution of knowledge to their home communities. Trophy hunting in the Arctic made possible performances of different forms of masculinity, not only the conquest and mastery of nature, but also the interest in and care for nature. Women also accompanied as family members and hunters, and women took part in the hunt more often than has been commonly noted.

Key words: Arctic, Polar, trophy hunting, gender, masculinity, tourism, expeditions, travel journals, nature

Contact: Lena Aarekol, lena.aarekol@uit.no

The nineteenth and the beginning of the twentieth century was a period when exploration, research, tourism and hunting went hand in hand in the Arctic. Trophy hunting was a type of tourist activity in the polar region long before the area became an arena of modern tourism. Although it was never an extensive practice, it was closely connected to the development of tourism in the north. Early travellers occasionally published personal accounts that often served as guide books for future travellers to the Arctic. One well-known example is the Scot John Laingie’s travel book A Journey to Spitzbergen (1807), which was printed in four editions and widely read by tourists heading for the north (Viken and Jørgensen 1998, 123; Snyder 2007, 15). By the mid-1800s, it was possible for the wealthy to make hunting and 
fishing trips in the Arctic that often represented a mixture of exploration and luxury tourism (Stonehouse and Snyder 2010). However, although Polar tourism in general has been a welldeveloped field in contemporary research, especially in the International Polar Tourism Research Network (Maher et al. 2011, 6-9), historic trophy hunting in the Arctic has nevertheless not been an extensively researched.

Few women were involved in trophy hunting, regardless of geography. Both the absence and presence of women can obviously be of importance in the development of a particular practice. Because trophy hunting tourism is primarily a male tourist practice, an understanding from a gender perspective is unavoidable. This article analyses different performances of masculinity in written accounts of Arctic trophy hunting expeditions from the period 1827-1914 to show how they demonstrate what may be defined as a specific trophy hunting masculinity.

\section{A Gender Perspective on Trophy Hunting}

Trophy hunting is defined as a hunt that is commonly undertaken in an area outside one's home area environment, and that generally involves wealthy people travelling around the world to kill large, often rare, animals. Such hunting trips for wild prey give high status and are not intended to obtain food or generate profit. This type of hunt also differs from the commercial business that local hunters, trappers and anglers do in the same areas. While the trophy hunter's main goal is to hunt for the sport, local hunters secure an income. Yet they hunt in the same areas and often for the same type of prey.

When British sporting gentlemen introduced trophy hunting to Scandinavia around 1830, it already had a history in other parts of the world (Sillanpää 2008, 60). In addition to hunting in Great Britain (in particular Scotland), British gentlemen went on hunting tours to their colonies in Africa and Asia. By the 1830s, the Scottish sporting grounds were overcrowded, the cost of hunting licences was rising, and the sportsmen turned towards spots further afield in order to have more adventurous and rough experiences. In Norway, both hunting and salmon fishing were popular sports. As early as in the 1880s, locals in Norway referred to the British sportsmen as "Salmon lords". Eventually, they were so numerous that the overcrowded salmon-fishing areas in Norway led them to an exploration of the Swedish wilderness (Sillanpää 2008, 68). Some even went further north during this period, and into the 
Arctic. The sportsmen in the north were not only British. Hunters from other European countries (mostly Germany and Austria) and America also visited.

Trophy hunting in the Arctic coincided with the period of Arctic Ocean imperialism (Drivenes 2004), that is, with expeditions setting out to conquer the poles, to search for possibilities of economic exploitation and scientific exploration. Concomitant with these approaches to the Arctic, what we might call a polar masculine understanding of man and nature evolved. The mastering of nature through the traditional values and knowledge cultivated by trappers, hunters, sailors and explorers was a defining feature of this distinct masculinity (Drivenes 2007, 76-78; Hauan 2007, 10; Knutsen 2007, 87-96). Qualities such, as physical strength, roughness, ingenuity, restless energy and a strong will to self-realization have been emphasized as necessary to survive in the harsh polar areas (Drivenes 2007, 76). So has an ethos of individualism, materialism and social mobility. Because of the overall modernization in the western world, including urbanization, migration and women's emancipation, during the late nineteenth and early twentieth centuries, this area was still considered a place where western males could exercise masculinity, challenge nature and be "men of the frontiers" (Bloom 1993, 32-33; Felski 1995, 20; Gordon 2006, 10; Karlsen 2011, 44-48). This implies that the Arctic trophy hunters did not enter an empty space, but an already masculinized arena in which trappers, explorers and adventurers had set the terms. Merely by travelling to the Arctic, the trophy hunters performed masculinity (Hansson 2009: 70). The characteristics of Arctic masculinity are commonly noted and often repeated. However, I argue that a study of trophy hunters can contribute to a broader understanding of masculinity in the Arctic that modify the widely accepted views.

\section{An Empirical Approach}

Heidi Hansson has shown that when tourists travelled in the Arctic they sometimes challenged the prevailing assumptions about the area. In her literary analysis of Lord Dufferin's famous Letters from High Latitudes (1857), Hansson demonstrates how the reading of travel narratives can contribute significantly to a gendered understanding of Arctic tourism. She finds that even though Dufferin uses his narrative to convey "the romance of the Arctic, which builds on the image of man pitted against the forces of harsh and dangerous nature" (Hansson 2009, 68), he nevertheless distances himself from the paradigm of heroic exploration and writes himself into a female rather than male tradition of travel writing. 
Hansson's conclusion contributes to a modification of the prevailing perspective on Arctic masculinity, but it is still necessary to investigate this further. Inspired by Hansson's analysis I have chosen to use several travel narratives as material for my analysis of Arctic trophy hunting and masculinity.

While I view travel narratives as sources of gendered perceptions of the Arctic, my purpose is also to explore the inception of this particular tourism practice and establish an insight into how this practice developed from the early 1800s until the outbreak of the First World War. However, my investigation is limited to material written by tourists who went from northern Norway to Svalbard and to the east coast of Greenland. My ambition is therefore not to provide a complete picture of trophy hunting during this long period, but to get a sense of this practice by analysing different texts in which trophy hunting plays an important part. To achieve this, I have chosen narratives of four tourist expeditions that took place in the period 1827-1914. The long time span allows me to provide an overview of the history and development of trophy hunting tourism in the Arctic.

Specifically, my chosen texts are narratives written by trophy hunters themselves, as well as one book written by an agent who arranged several hunting expeditions for tourists. Although the narratives are based on journal notes written during hunting expeditions, they were later rewritten and published in book form. As source material, they provide a first-hand impression of the travel and hunt, even though they were obviously edited before publication.

The trophy hunters I have chosen describe expeditions undertaken in the years 1827, 1859, 1881 and 1906. The German traveller Bartolomäus von Löwenigh (1799-1853), who visited the Svalbard archipelago and Bear Island (Bjørnøya) in August and September 1827 during a six-week sailing cruise and his travel, constitutes a natural starting point. Together with the Norwegian Balthazar Mathias Keilhau (1779-1858), he was among the first sportsmen and tourists journeying to discover the Arctic in their private yachts (Elstad 2004, 477). Hunting opportunities constituted an important part of the venture that took them to both the Svalbard archipelago and Bear Island (Bjørnøya). Löwenigh’s book Reise Nach Spitzbergen [Journey to Spitsbergen], published in 1830, consists of three different travel letters, but only one of them - a total of 10 pages - depicts the journey into the Arctic, (Löweingh 1830, according to Heintz 1959/60, 103)1. He does not mention that he took on board an extra passenger, the naturalist Keilhau. In fact, Keilhau participated on the entire cruise, which has later been regarded as the first Norwegian scientific exploration of Bear Island and Svalbard within the fields of botany, palaeontology and geology. During the trip he took copious notes and in 1831 published the book Reise i Öst- og Vest-Finmarken samt til 
Beeren-Eiland og Spitsbergen, i Aarene 1827 og 1828 [A journey to East and West Finnmark, Bear Island and Spitsbergen in the years 1827 and 1828]. In two long chapters, Keilhau here describes his Arctic adventure and research.

Some thirty years later, during the summers of 1858 and 1859, the Scotsman Sir James Lamont of Knockdow embarked on two cruises to Svalbard. While spending the summer in Norway in 1858, he had heard reports of excellent hunting conditions in Svalbard. His trip to the archipelago was short that summer since it was late in the season, but it convinced him to return the following year (Lamont 1861, 17-18). His friend Lord David Kennedy, chosen because of his trophy hunting experiences in India, accompanied him on this six-week long tourist expedition (Lamont 1861, 20). I have based my analysis on the 282-page book he published after these cruises: Seasons with the Sea-Horses (1861). It is based on his journal and illustrated with eight drawings and a map with the author's route.

In 1881 Henry D. Clodius organized the first true Svalbard tourist cruise, scheduled for 14 days of cruising and hunting in Svalbard waters. On board the cruise ship Pallas (a 507-tonne vessel) there were passengers from England, Germany and Scandinavia (Reilly 2009, 38). The party consisted of 28 tourists, seven of whom were women. Three of the male passengers, including the British Abel Chapman (1851-1929), published their observations. Chapman describes himself as a big-game hunter, having practised the craft since boyhood. He had visited Scandinavia to hunt and fish 23 times during a period of 17 years and published several books about his experiences, Wild Norway (1897), The Borders and Beyond: Arctic, Cheviot, Tropic (1924), and Retrospect: Reminiscences and Impressions of a Hunter-Naturalist in Three Continents 1851-1928 (1928). His love of natural history and especially ornithology plays a part in his recollections of the cruise in his 1897 book, and the chapter "Spitsbergen" only deals with the bird life in the summer without mentioning the hunt (Chapman 1897, 341-42). When he did so, in the book from 1928, he limited himself to one chapter.

A quarter of a century later, in the summer of 1906, the American Maximilian Charles Fleischmann and his wife Sarah went on a 10-week honeymoon voyage with Magnus Klerck Giæver and his vessel the Laura from Tromsø to the Arctic. Fleischmann’s sister, Bettie Fleischmann Holmes, her husband, Christian R. Holmes, their 11-year old son Carl and Fleischman's friend Noel C. Livingstone Learmont also accompanied the newlyweds (Fleischman 1909, 23; Giæver 1944, 74). Apart from Learmont, who was British, they were all from Cincinnati. As an heir to a successful yeast company, Fleischman had the means to travel as a trophy hunter around the world at the age of 29, and the following year he also 
went hunting in Africa and Alaska (Wheeler 1985, 10-12). The journals he kept during his trips were published in 1909 under the title After Big Game in Arctic and Tropic: A Sportsman's Note-Book of the Chase off Greenland and Alaska; In Africa, Norway, Spitsbergen and the Cassair and dedicated to his wife Sarah. Apparently, he only printed a few copies as gifts to friends and family (Wheeler 1985, 15).

In addition, Fleischmann's sister, Bettie Fleischmann Holmes, published an account of her experiences in The Log of the Laura in Polar Seas, a book of 135 pages illustrated with 59 photographs, in 1907. Since her brother's journal was published two years later, it is likely that he was inspired by her narrative, and he even cites her journal. Holmes' Log is the only text written by a woman that I discuss.

The manager of Fleishman's 1906 expedition, Magnus Klerck Giæver, played a central role in the trophy hunting business in early 1900s. Born into a merchant family that was involved in the whaling business in northern Norway, he used the family's vessel the Ino, which was rebuilt and reinforced for sailing in the Arctic Ocean in 1896. After the English ornithologist Henry J. Pearson hired the Ino and its crew for a two-month expedition to the Vaygach Islands and Novaya Zemlya in 1897, Giæver renamed the vessel the Laura in honour of Pearson’s wife Laura (Giæver 1944, 19). In 1944 Giæver published the book Turister og jegere i Ishavet [Tourists and hunters in the Arctic Ocean], in which he recollects different hunting expeditions in the Arctic in the period 1904-1914. It is a conglomeration of various anecdotes, facts, place names and hunting stories, covering 160 pages illustrated with 38 photographs. The book is entertaining but complicated to use as a source because the narratives are disorganized and retold in a chaotic manner. Its publication 30 years after Giæver gave up his trophy hunting business may account for the lack of accurate details, even though he had referred to his old journal notes (Giæver 1944, 162).

In my reading of the texts I have focused on two main questions. First, how did the tourists plan, organize and execute their hunting trips in the Arctic? Second, how did they reflect upon nature and hunting during their travels? These questions are significant in my analyses because they will shed light on how trophy hunting masculinity was performed.

When entering the Arctic hunting ground, the trophy hunters also entered a new and unknown environment, which made them dependent on local crews and their knowledge. This suggests that their performance of masculinity must have been shaped in the encounter between the traditional knowledge represented by the crew and the norms of the visiting upper-class hunting tourists. In this context, a focus on masculinity implies a relational analysis involving such dimensions as time and place, since what counts as masculinity varies 
according to social, economic and political formations, which can change over time (Ekenstam 2006; Arnold \& Brady 2011, 5; Connell 2012, 5-9). Inspired by John Tosh’ call for a revitalized historical approach on masculinity, re-engaging with agency, behaviour and experience (Tosh 2011, 20), my aim is not to determine what trophy hunting masculinity is, but to analyse what masculinity has been within that particular context. As one example, I look at what kind of masculinity appears in the planning of the hunting tours. This implies an interrogation of masculinity by documenting different empirical examples that contributes to a re-thinking of trophy hunting in the Arctic (Aarekol 2015).

\section{How to Organize an Arctic Trophy Hunting Expedition}

Löwenigh does not write anything about how he had planned his 1827 expedition in his journal. He simply recounts that he hired the Norwegian vessel the Haapet from the Russian consul in Hammerfest and lists the crew just as oarsmen, harpooners and spear javelin throwers. They were probably men from northern Norway, with knowledge of fishing and hunting. Lamont chooses a different approach and includes a thick description of how he organized his expedition in 1859. After his first summer in Norway and Svalbard he had contacted the British Consul in Hammerfest, requesting leave to rent the small vessel (a sloop) Anna Louisa for the summer season. Lamont writes that he found this vessel extremely smelly, ugly, and clumsy and rigged with a particularly ill-fitting mainsail. Consequently, he sailed the more luxurious Ginerva, the same vessel that had taken him from Scotland to Hammerfest, to Svalbard, and only moved on board the Anna Louisa when it was necessary because of the hunt and ice conditions (Lamont 1861, 31).

According to Lamont, the best and boldest seamen were the sealers of northern Norway, whom he calls "the true descendants and successors of the gallant Vikings and Berserkars” (Lamont 1861, 59). Partly because of this, he paid his crew a fixed rate and hoped that they would do as he wished instead of getting a full cargo on their own (Lamont 1861, 59-60). The crew on the Anna Louisa consisted of a captain, two men rated as harpooners and mates, a cook and eight other seamen. Only the captain and two of the crew had been to Svalbard before. During the trip, Lamont replaced one of the harpooners because of incompetence and appointed another man in that position (Lamont 1861, 85). Still, overall he expresses satisfaction with the crew and sadness to part with the men when the cruise ended, noting that he had "never met with a more hard-working, docile, uncomplaining, and good humoured lot of fellows” (Lamont 1861, 266). 
The cruise to Svalbard in which Chapman took part in 1881 represented a shift in the organization of cruises to the Arctic. From now on, it was possible to buy tickets for a prearranged tour. An advertising campaign in European hunting magazines had promised the participants on this particular cruise polar bear, seal, reindeer and walrus hunting as well as fowling. However, the cruise was not a success and, in order to save money, the captain decided to return after just over a week. Naturally, the passengers were upset and back in Tromsø they criticized the tour in an advertisement in a local newspaper, describing it as the “Spitsbergen Swindle” (Reilly 2009, 39-40). These events are not recounted in Chapman’s narrative, nor does he mention any practicalities or how the cruise was organized. Instead, his books are characterized by comprehensive descriptions of nature and wildlife.

Fleischmann's tourist expedition in 1906 was not a large pre-arranged cruise, but it was booked and arranged the previous winter, when Fleischman corresponded with Giæver to hire the Laura. Although this vessel had a rather small engine, “pony-power” in Holmes’ words (Holmes 1907, 8), the siblings recommend it in their journals as suitable for their purposes because it had a darkroom and space for taxidermy and the collection of flora. This hunting party could rely on a crew of 18 Norwegians, including the experienced Captain Jens Øien (Holmes 1907, 8-11; Fleischmann 1909, 16-18). Even the dog they purchased in Tromsø, Napoleon, had a reputation as an experienced bear hunter and expedition member, because he had participated in the previous Baldwin-Ziegler Polar expedition (1903-5). With the exception of an episode with an intoxicated chef, the party express satisfaction with the crew during their time on board from 17 June until 28 August.

As this overview of accounts of tourist hunting expeditions indicates, the tourists throughout the period I have studied chose to organize their Arctic hunting expeditions in the same way, by booking a trip or a vessel fit for their purpose and a more or less experienced crew from northern Norway. All were clearly motivated by an urge to experience adventures and exploration, and their voyages to the far north imply that they were willing to expose themselves to risk and danger. Löwenigh even opens his travel letter with a motto referring to the danger, “Annihilation threatened day and night from all sides”, a quote from the famous the Russian scientist and writer Mikhail Lomonosov (1711-65). Indeed, as in Lord Dufferin's travel narrative, risk and danger seem to have been perceived as giving the Arctic environment an intrinsic value, a masculine character of its own. The excitement lies in the challenges of overcoming hazards through possessing the right skills or having made the right preparations, together with an awareness of the risks that exposure to danger always involves (Gordon 2006, 4). When the trophy hunters went to the Arctic, nature itself represented 
danger in the form of extreme cold, ice, turbulent ocean-crossings and difficult weather conditions, while the right knowledge, experience and skills could reduce the risks (Drivenes 2007, 78). The planning and organizing of tourists expeditions in advance were therefore all about reducing the risks of travelling in the Arctic, and one important element in this planning was hiring the right skilled crew when entering an unknown area and environment.

Although both Lamont and the members of the Fleischman tourist expedition express a general satisfaction with the crew onboard their ships, Löwenigh characterizes the captain as incompetent after he made a navigational mistake that caused them to end up at a wrong island (Löweingh 1830 according to Heintz 1959/60: 112). On another occasion, when the vessel was in danger of being crushed by the ice, the captain abandoned it while Löwenigh decided to stay on board. After eight hours of drifting among the ice floes, the captain returned. Keilhau also mentions this episode, but concludes that the captain had every reason to be distressed in that difficult situation (Keilhau [1831] 1973, 144-45). The day after this event, the ice had almost disappeared from the surface of the ocean, but they experienced heavy snowfall. Löwenigh then ordered the captain to sail further north. However, despite the fact that there were favourable conditions for sailing northwards with a southerly wind, the captain contested Löwenig and sailed up-wind. The result was that they did not reach any further north (Löweingh 1830, according to Heintz 1959/60, 106-7).

The captain probably lacked the necessary skills for the difficult weather conditions, but he also knew about the dangers and must have been afraid of being caught in the ice. Actually, before the 1850s few Norwegian captains had much experience of sailing in the Arctic Ocean (Arlov 2004; Nielsen 2004). In his journal, Löwenigh portrays himself as the one in control while the captain is viewed as being both cowardly and inept as a sailor. Löwenigh also lacked the relevant experience, but he had either an overwhelming urge to get as far north as possible or was too inexperienced to understand the real danger of sailing in the Arctic Ocean. While the captain acted upon his knowledge, Löwenigh wanted to ignore the weather conditions in order to achieve a record. This conflict adds perspectives to the understanding of Arctic masculinity. The captain and his crew represented a tradition of practical and experience-based masculinity with their knowledge from sailing and hunting in the North. When participating in the pre-modern tourist industry, they also entered an era of modernity in business and masculinity. Although several of the trophy hunters had travelled all over the world for adventures, the masculinity they represented must be seen as a continuation of a tradition of sporting gentlemen, who relied on footmen when traveling and hunting (Ekenstam 2006, 16). 
One sign that the trophy hunters saw themselves as sporting gentlemen is that very few of them seem to have disputed their captain's decisions during the expeditions. Instead, unlike Löwenigh, they put all their trust in the captain and their crew. After navigating through the ice trying to reach the east coast of Greenland, Holmes puts it like this: “After repeatedly starting and stopping we were finally free without damage to the ship, but realizing more fully than ever how much our safety depended upon the never-ceasing vigilance, judgement and experience of our officers and crew" (Holmes 1907, 90).

Particularly during the actual hunt, the trophy hunters were dependent on the crews. Lamont had obviously taken this into account when he ordered two custom-made rowboats in Hammerfest "of a size slightly larger than those commonly used, so as to admit of an amateur sitting comfortably in the stern without his having necessarily to act as one of the boat's crew” (Lamont 1861, 19). In this way he and his friend could focus solely on the hunt itself:

Meantime Lord David's boat is carried past us at eight miles an hour in full tow of two enormous bulls [walruses], with his lordship sitting in the stern like Neptune in his car, but holding in his hand, instead of the trident of the marine god, a much more effective weapon in the shape of a four-barrelled rifle (Lamont 1861, 83).

One of the illustrations in Lamont's narrative, with the caption "She-bear and her cubs", likewise underpins their role as sporting gentlemen in the hunt compared to the crew (Lamont 1861, 128). In the left corner, Lamont and Lord David observe the prey from a distance, while members of the crew approach the live cubs that sit on their dead mother. In this situation, the sporting gentlemen let the crew capture and deal with the aggressive cubs. Also in Chapman's account, the crew on the cruise plays an important role during hunts. One episode, when the harpooner Kjeldsen whispers “Isbjorn (Ice-bear)” while they are out hunting from a small boat, is described by Chapman as "the climax of the Arctic sensation” (Chapman 1928, 82).

Giæver, who was a facilitator of hunting tourism in the Arctic, describes how he, his captain and crew helped and guided the trophy hunters. When hunting polar bears from the vessel, one trick was to put a piece of blubber on the heating boiler in an attempt to attract the bears by the delicious smell (Giæver 1944, 55). When the Fleischman party hunted for polar bears they often shot from the boat deck after the crew and some of the trophy hunters had formed a driving-line and chased the bear close enough (Holmes 1907, 87, 92, 101). The crew did not only aid in the hunt, they also carried the carcasses back to the vessel and took care of the bagged hunt, as they were obligated to do. They skinned the animals, removed the 
blubber, salted and prepared the skins. They also marked the animals with the hunter's name and a number (Holmes 1907, 39; Giæver 1944, 60).

The use of the crew as footmen, rowers and helpers indicates that trophy hunting as a gentleman's sport represented an aristocratic masculinity characterized by self-discipline, action force, high moral and strength of character (Ekenstam 2006, 16). In their well-planned expeditions, they took control over the hard conditions by choosing the right equipment and crew. By entrusting the crew with the hard and dirty work, the trophy hunters themselves could distance themselves from the traditional way of hunting. They only participated in the hunt as gentlemen. Descriptions of the hunt itself support such an interpretation. In the next section, I will analyse how the trophy hunters conducted the hunt, their views on about nature and their purpose.

\section{"How to shoot a walrus"}

Both Löweingh and Keilhau seem to have been particularly fascinated by walrus hunting, which they describe as bloody but powerful, and as a significant experience. One episode in Löweingh's account starts with the following observation at Kvalpynten, the southernmost point of the island of Edgeøya: "On a soft rocking floe, slumbered a legion of walrus. Such an abundance of these monsters could one not find anywhere else on Spitsbergen” (Löweingh 1830, according to Heintz 1959/60, 107). Obviously, he and Keilhau performed a classical sportsman's hunt with comprehensive help from the crew. While Löwenigh sat in a rowboat together with an oarsman, one harpooner and four javelin throwers in another rowboat were ready to attack while Löwenigh observed the dangerous stabbing from a safe distance. They killed 16 of the walruses, and Löwenigh comments that he plans to use the moustaches as tooth picks at formal parties (Löweingh 1830, according to Heintz 1959/60, 107-8). Polar bears, in contrast, seem not to have been a primary target. According to Keilhau, they only killed two polar bears that by accident had strayed close to the vessel.

During their summer trip, Lamont and Lord David hunted almost all the wildlife they encountered in the Arctic. "In all my sporting experience,” Lamont writes, "I never saw anything to equal the wild excitements of these hunts” (Lamont 1861, 81) (see Figure 1). In a later book, Yachting in the Arctic Seas (1876), he describes walrus as a challenge for a real hunter: 
No one who has not tried it will readily believe how extremely difficult it is to shoot an old bull-walrus clean dead. The front or sides of his head may be knocked all to pieces with bullets, and the animal yet has sufficient sense and strength to enable him to swim and dive out of reach (Lamont 1876, 69).
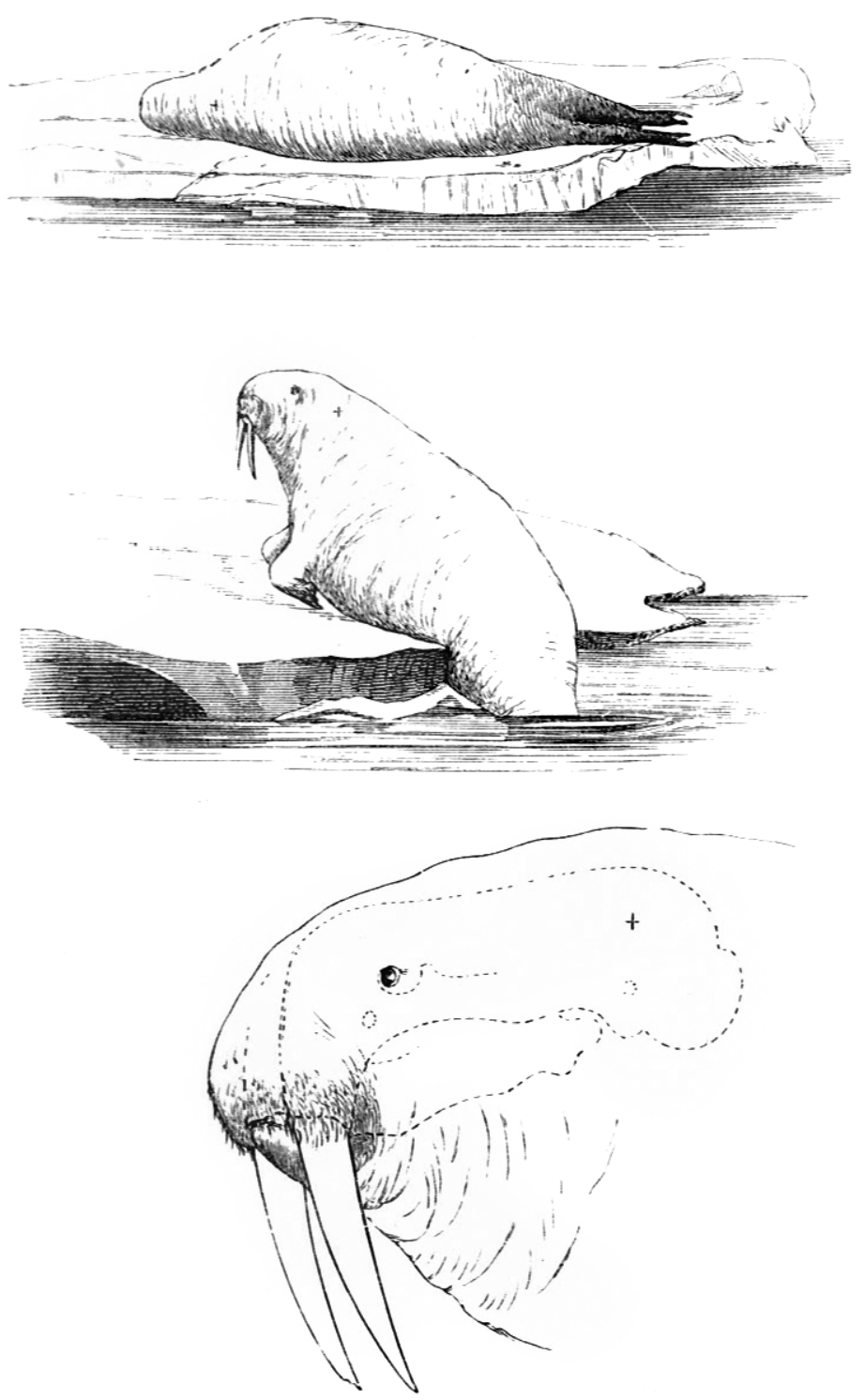

How to Shoot a Walrus.

(The fosition of the brain is shown by the cross.)

Figur 1. "How to shoot a walrus. (The position of the brain is shown by the cross)", as illustrated by Lamont $(1876,69)$.

This distinction between walrus hunting and hunting for other large mammals suggests that there was a hierarchy of animals to hunt. Lamont's comprehensive descriptions of how dangerous this hunt was strengthen such an interpretation. But Lamont's book contains 
hunting stories of all types of prey and also includes discussions about the moral and emotional aspects of hunting.

Presumably to demonstrate his Christian morals, he emphasizes that unlike many other hunting parties, he does not hunt on Sundays (Lamont 1861, 87-8). He also avoids killing withoutacquiring the prey, considering that "nothing can be more distasteful or unsatisfactory to the feeling of a true sportsman than taking the life of anything which is to be of no use when dead” (Lamont 1861, 66). When out reindeer hunting, he believes that he could have shot many more because they were so tame, but is "disgusted with such burlesque sport and left them alone” (Lamont 1861, 228). To underline his own hunting ethics, moreover, he retells a hunting story from 1852 about four boats and a crew of 16 men who went walrus hunting in the Thousands Islands. They killed 900 walruses without having the possibility of taking more than a small number of the catch onto their vessels. When Lamont visited the islands in 1858, one could still find skulls and tusks on the beach. Finding such unnecessary killing so upsetting that he names it a "Frightful Massacre", he wonders why no one had shouted “Hold, enough!” before they had slaughtered so many (Lamont 1861, 175, 176).

However, Lamont's accounts of hunting are contradictory. On the one hand, he seems concerned with the ethics of hunting and expresses consideration both for the animals and nature itself. On the other hand, he describes quite unsentimentally how he and Lord David "killed a lot of eider-ducks and fulmars by knocking them off their nests with sticks and stones, which they were actually tame and foolish enough to allow” (Lamont 1861, 91). While harpooning a walrus cow and her calf, he finds the maternal affection displayed interesting and does not think he will ever forget "the faces of the old walrus and her calf as they looked back at the boat!” (Lamont 1861, 69-70). Yet he kept on hunting both adult walruses and calves.

Since the Svalbard cruise in 1881 only lasted a week there was probably little time for hunting, and Chapman only refers to one hunting episode in his books. They had then been stalking a polar bear in the water when "a rifle-shot rang out and instantly the sleep of Nature was changed to the sleep of Death” (Chapman 1928, 82). This turns into a disappointment when they realize that they have not killed a polar bear but a big bearded seal (Phoca barbata). In the hierarchy of types of prey, a seal was obviously ranked lower than a polar bear. Variables regarding the size of the animal, how dangerous it is to hunt, its sex and age would also play a role in such a ranking. Presumably, it would be a more masculine achievement to hunt a big male polar bear than a than a female polar bear cub. 
Whereas there are no indications that any of the female cruise passengers in 1881 hunted, except that they used fishing tackle to catch cod from the ship (Reilley 2009, 37-8), Holmes writes that she and Fleischman's wife took part in the everyday hunting on the 1906 expedition. Holmes' log is one example that indicates that women took part in the hunt more often than has been commonly noted. She writes that while the men and her son Carl go in the rowboats or on the ice to hunt, the women hunt mammals from the boat deck. However, they do go ashore to hunt for birds equipped with a .303 Savage rifle each, the same as what Carl uses (Fleischman 1909, 23-5).

Holmes also describes how they hunt for polar bears with cubs. According to her account, there were three steps in polar bear hunt from the deck: first observing, second photographing, and third - even though she finds it "thrilling to see the old one followed by her young” as she puts it - a "well-directed shot” (Holmes 1907, 58). Like Lamont, she touches upon the emotional side of hunting by focusing on the maternal instinct in mammals. Describing her observation of a polar bear mother's behavior when she tries to protect her cubs against their persecutors, she finds that their "keenly developed maternal instinct, shown by all wild animals in guarding their young from danger, is infinitely pathetic to see, and despite the 'lust of the kill' the hunter cannot but be touched by it” (Holmes 1907, 95; Fleischman 1909, 74). On another occasion, when they catch a living polar bear cub, she calls it a "poor little beast" (Holmes 1907, 96). Nevertheless, her narrative is by no means sentimental. While the men shoot the mother bears, the female hunters enjoy sending a bullet into the cubs (Holmes 1907, 59, 97). This was “fine day's sport”, she concludes, and "we live in a continual state of hopeful expectancy” (Holmes 1907, 93, 80). Holmes' way of referring to the hunt indicates that she, as much as the men, enjoyed being on board and the excitement of the hunt itself.

Holmes' brother, Fleischmann, who still thought that it was unusual for ladies to participate on hunting expeditions, wrote that his sister and wife "took a decided hand in this hunt; the first women, without doubt, to shoot a bear in these wastes” (Fleischman 1909, 73). Perhaps it was more extraordinary for women to participate than (male) children. At least none of the journals points out that it was remarkable that a boy of 11 took part in the hunt by shooting seals and birds. Although Fleischmann writes that he was criticized for taking women along this trip, he expresses "no regret having taking them, they having stood the cruise surprisingly well” (Fleischman 1909, 23-24). His wife and sister-in-law may also have impressed him with their hunting skills. Yet this does not have a prominent place in his narrative. Nor does Giæver give much attention to the female tourists in his book, apart from 
expressions of deepest sympathy with the female guests because he imagines that the cruise could not have satisfied their “refined taste organs” (Giæver 1944, 80). Even Fleischman’s biographer does not mention that his wife Sarah was a hunter, only referring to her as "an experienced sportswoman” (Wheeler 1985, 17). Perhaps women’s participation was seen as making the hunt less adventurous or important. Donna Haraway cites the trophy hunter and taxidermist Carl Akeley, who argued that he took women with him on gorilla hunts in the 1920s because "[a]s a naturalist interested in preserving wild life, I was glad to do anything that makes killing animals less attractive” (Haraway 1989, 34). However, the participation of women did not seem to have changed how the hunt was performed, and hunting only from the deck they obviously had a more secluded role. That said, there is nothing in Holmes' descriptions of the cruise, the hunt or nature that differs from her brother's.

\section{Documenting Nature}

As part of their Arctic tourist expeditions, some trophy hunters also had scientific ambitions to describe nature, take measurements and collect specimens (also alive) to bring back home with them even though they were amateurs without any formal science background.

For Keilhau, who joined Löwening on his expedition, scientific documentation seems to have been a major motive. For example, adhering to the norm of naturalist travels he uses his four-day stay on Bear Island to measure the temperature every day and collect species of phanerogam (seed-bearing plants) and cryptogam (plants that reproduce without seeds, like moss and lichens) (Keilhau [1831] 1973, 133). Later he donated one polar bear skull and skin to the zoology collection in the University Museum in Christiania (now Oslo) (Keilhau [1831] 1973, 162).

When Lamont returned to Hammerfest, he sold most of a cargo that comprised 240 heads in total (of 48 walruses, 88 seals, eight polar bears, one white whale and 61 reindeer). Although the price he fetched was low, it almost covered his expenses. He kept six bear skins, all the ivory and the young bears. During summers it was quite common to hunt for polar bears and keep the cubs and put them up for sale. Because the British market, according to Lamont, was overstocked with polar bear cubs at the time, his two live cubs ended up in a zoological garden in Paris (Lamont 1861, 267-9). Lamont also made geographical surveys and collected different specimens. His book includes an appendix with a list of specimens of rocks, fossils and animals that were sent to the Geological Society and later ended up in museum collections. His books shows that he was interested in what the animals looked like, their behaviour and how they lived. He even opened the stomachs of seals and walruses to get 
first-hand information on what they ate. That made him doubt what the English researcher and explorer William Scoresby (1789-1857) had asserted - that walrus ate seals (Lamont 1861, 70, 139). Lamont also confronted previous perceptions of Arctic environmental conditions. Before travelling to Svalbard he had clearly read Lord Dufferin's Letters from High Altitudes and argues that his lordship was wrong in stating that driftwood was brought to Svalbard by the Gulf Stream and that it instead must have its origin in Siberia (Lamont 1861, 92-4).

Profoundly inspired by Charles Darwin’s ideas, Lamont initiated a correspondence with the naturalist, and Darwin responded with sporadic yet encouraging letters (Devlin 2015). In particular, Lamont expounded upon the evolution of walrus and polar bear, comparing it with knowledge gathered on earlier trips to Africa (Lamont 1861, 248-57). He was convinced that "an attentive study of the Arctic fauna is capable of throwing light on some debated questions in Natural History", as well as of "strengthening the theory of progressive development” (Lamont 1861, 246).

As mentioned, Chapman was a passionate big game hunter all his life and went on several hunting tours to Europe and Africa in addition to Norway. Many of his trophies ended up in different museum collections, such as at the Natural History Museum in London and the Great North Museum in Newcastle. Even today the Game Head collection in the Great North Museum is dominated by Chapman's donations of mammals (https://greatnorthmuseum.org.uk/collections/zoology). Chapman also engaged in the establishment of nature reserves to preserve breeding grounds for flamingos and to save the Spanish wild goat (http://www.sunderlandecho.com/news/the-amazing-life-times-and-legacyof-sunderland-s-big-game-hunter-1-1105964).

In her journal, Holmes kept a meteorological diary based on measurement of the wind and temperature of the air and water. As the only one of the trophy hunters I have examined, she published her data set in a meteorological table together with a game list in the end of the book. The latter is also more systematic than the report of the other trophy hunters, which suggests that she had a serious interest in her observations. According to her report, her party killed a total of 154 mammals (103 seals, 23 bears, 24 reindeers, 4 foxes) and 527 birds. This was also in line with the six objectives for the expedition that Fleischmann listed in his book. Three of the objectives were geographical, such approaching Greenland and making short shore expeditions; the other three concerned animals and nature. Besides securing what shooting they could, they were attempting collecting specimens of bird life and live specimens of musk oxen and polar bears (Fleischman 1909, 15). During the expedition itself, the hunting party took the taxidermy work seriously; they skinned and prepared the bird 
specimens with arsenic, which they found difficult because the Arctic birds were so full of fat. Later they donated the specimens to the Santa Barbara Museum of Natural History. What happened to the two cubs that they captured alive and named Tommy and Thelma is unknown, but one may assume that they ended up in a Zoo.

The previous examples show that the trophy hunters' documentation of Arctic nature ended up partly in their private homes, partly in museums, partly in other educational institutions and zoos. Geological samples, bird skins or plants were also regarded as trophies like the skulls of large mammals. Documenting nature in this way may be seen as an attempt to conquer and control nature. This activity also had an educational purpose and was an expression of a paternalistic or fatherly masculinity ideal (Tosh 2006, 25-9). The generous donations of Arctic samples therefore strengthen my assumption that trophy hunters acted on a masculine ideal that they should contribute to the education of their hometown communities and future generations in general. Without any scientific training, they sincerely considered that their task was to contribute to museum collections or the wildlife in zoos. This also coincides with a nineteenth-century gentlemanly sporting spirit as a masculine ideal. At the same time, scientific ambitions provided a more serious legitimation of the expeditions than the hunt for trophies.

\section{Arctic Trophy-Hunting Masculinities}

The ambition of this article has been to contribute to a discrete history of masculinity within the context of trophy hunting. My empirical approach, a reading of the trophy hunters' narratives from 1827, 1860, 1881 and 1906, gives insight into how (male) hunting tourists arranged their trips and their purposes. This reading constitutes a basis for a better understanding of this practise from a gendered perspective. In the following discussion and concluding remarks, I will focus on trophy hunting, tourism and masculinity.

All of the four tourist expeditions that I have investigated were dependent on the vessel and the crew they hired. During the hunt the hunters also had to depend on the captain and crew; they needed help to find game and to chase the animals closer to the ship, and oarsmen in their small hunting boats had the dirty job of attending to and preparing the dead animals. They relied on the captain and his crew to master the harsh Arctic condition, leaving them to concentrate on enjoying the landscape and hunting for trophies. Only Löwenigh contested the captain's aptitude openly, while the other tourists praised their captains' expertise and success in taking them to the Arctic and back again. Over such a long time span it is not surprising that the arrangement of tourist expeditions changed. Yet some aspects 
remained quite similar. Until the first Svalbard cruise in 1881, the hunters organized their own trips by booking a suitable vessel that was ordinarily used for other purposes. From then on, it was possible to buy a ticket for prearranged cruise, although they were never offered on regular basis. From 1904 it was also possible to book cruises via a commercial agent that specialized in trophy hunting. Trophy hunting tourism may be seen as a precursor to modern wildlife tourism, even though the business was of a quite different character from today's modern mass tourism in the polar regions. As tourists, the trophy hunters exemplify a contradictory masculinity. They were adventurous at the same time as they were concerned with safety and minimising potential risks.

The Arctic was perceived as a hunting ground for wildlife, in particular marine mammals. Polar bears and walruses were the main attraction, while seals and terrestrial mammals, such as the Svalbard reindeer and musk oxen in Greenland, were also hunting targets. In their accounts, the trophy hunters expressed interest in nature not only to enable them to hunt the species they encountered; they also seem to have had a genuine interest in the history of the area and the landscape itself. The hunting-tourism business evolved as a practice between exploration and research. When the hunters refer to the history of earlier explorations of the Arctic, they use it as a background to their own experiences and to place their narratives in a historic context of exploration. By collecting specimens and taking them back to museums, the hunters also contributed to materialising the natural and cultural heritage of the Arctic in their home countries. This practice was also a way of performing masculinity. While the hunters' primary goal was to collect whatever they came across of wildlife, they also seem to have had an interest in understanding nature as a whole, both as a way mastering it and by describing it to educate themselves and others.

The journals chosen as material for this article suggest that women first participated in the Arctic trophy hunting in the early twentieth century. However, this does not mean that women had not been hunting in the Arctic earlier. While the Fleischman tourist expedition granted a place for wives as hunters on board this cruise, their participation has been undercommunicated afterwards.

Using masculinity as a pivot demonstrates that trophy hunting was a phenomenon that obtained more than just hunting for trophies and potency. My analyses of journals written by trophy hunters support the assumption that Arctic masculinity has consisted of more than qualities such as physical strength, roughness, ingenuity, restless energy and a strong will to self-realization through history. Entering an already masculinized arena based on the traditional values and knowledge of trappers, sailors and explorers, the trophy hunters 
modified the terms of the existing Arctic masculine behaviour. Trophy hunting opened up to a performance of different forms of masculinity, not only the conquest and mastery of nature, but also the interest in and care for nature. The masculinity of upper-class trophy hunters was shaped by aristocratic ideals in which rationality, discipline and sportsmanship were important. Within this trophy-hunting masculine practice women, too, were allowed to hunt, but without leading to noteworthy changes in feminine conventions of behaviour.

\section{References}

Aarekol, Lena. 2015. "Maskulinitet og trofejakt." Nordlit 35: 189-203.

Arlov, Thor B. 2004. "Den første ishavsbyen." In Norsk Polarhistorie, vol. 3, edited by Einar Arne Drivenes, Harald Dag Jølle and Ketil Zachariassen, 39-45. Oslo: Gyldendal.

Bloom, Lisa. 1993. Gender on Ice: American Ideologies of Polar Expeditions. Minneapolis: University of Minnesota Press.

Arnold, John H. \& Brady, Sean. 2011. What is Masculinity? Historical Dynamics from Antiquity to the Contemporary World. London: Palgrave Macmillian.

Chapman, Abel. 1897. Wild Norway: With Chapters on Spitsbergen, Denmark etc. London: Arnold.

Chapman, Abel. 1924. The Borders and Beyond: Arctic, Cheviot, Tropic. London: Gurney and Jackson.

Chapman, Abel. 1928. Retrospect: Reminiscences and Impressions of a Hunter - Naturalist in Three Continents 1851-1928. London: Gurney and Jackson.

Devlin, C. Leah. 2015. "The Letters between James Lamont and Charles Darwin on Arctic Fauna". Polar Record: 51(5): 492-500.

Conell, Raewyn. 2012. "Masculinity research and global change". MCS - Masculinity and social change, 1 (1): 4-18. 
Drivenes, Einar, Arne. 2007. "Polarmannen". Kvinnforsks skriftserie: 6/2007: 51-58.

Drivenes, Einar, Arne 2004. "Ishavsimperialismen", in Norsk Polarhistorie vol 2, edited by Einar Arne Drivenes, Harald Dag Jølle and Ketil Zachariassen, 157-257. Oslo, Gyldendahl.

Ekenstam, Claes. 2006. "Män, manlighet og omanlighet i historien", in Män i Norden.

Manlighet och modernitet 1840-1940, edited by Claes Ekenstam \& Jørgen Lorenzen,13-43. Stockholm: Gidlunds förlag.

Elstad, Åsa. 2004. "Polarturisme", in Norsk Polarhistorie vol. 3, edited by Einar Arne Drivenes, Harald Dag Jølle and Ketil Zachariassen, 477-520. Oslo, Gyldendal.

Felski, Rita. 2005. The Gender of Modernity. England: Harvard University Press.

Fleischmann, Max C. 1909. After Big Game In Arctic and Tropic: A Sportsman's Note-Book of the Chase Off Greenland and Alaska; In Africa, Norway, Spitsbergen and the Cassair.

Cincinnati, $\mathrm{OH}$ : The Jennings and Graham Press.

Giæver, Magnus K. 1944. Turister og jegere i ishavet. Oslo: Tanum.

Gordon, Robert J. (2006). "Introduction", in Tarzan was an Eco-Tourist... and other Tales in the Anthropology of Adventure, edited by Luis A. Vivanco, \& Robert J. Gordon. New York \& Oxford: Berghahn Books.

Hansson, Heidi 2009. "The Gentleman’s North: Lord Dufferin and the Beginnings of Arctic Tourism". Studies in Travel Writing 13 (1): 61-73.

Haraway, Donna. 1989. Primate Visions: Gender, Race, and Nature in the World of Modern Science. New York and London: Routledge.

Hauan, Marit Anne. 2007. "Maskuliniteter i Nord", Kvinnforsks skriftserie, 6/2007.

Holmes, Bettie. 1907. The Log of Laura. Cambridge:The University press.

Löweingh, Bartolomäus. 1830 [1959/60] "Reise nach Spitzbergen", in Heintz, Anatol "Reise til Spitsbergen for 153 år siden". Polarboken: 103-12.

Karlsen, Silje Solheim. 2011. "Triumf, lojalitet, avstand. Fridtjof Nansens Fram-ekspedisjon (1893-1896) - og bøker i dens kjølvann", Phd. diss., UIT, The Arctic University of Norway.

Keilhau, Balthazar Mathias. 1831 [1973]. Reise i Öst- og Vest-Finnmarken samt til BeerenEiland og Spitsbergen I Aarene 1827 og 1828. Oslo: Børsum.

Knutsen, Nils Magne. 2007. "Barsk og sterk - eller full og infantil? Mannsbildet i norsk polarlitteratur". Kvinnforsks skriftserie, 6/2007: 59-72.

Lamont, James. 1861. Seasons with the Sea-Horses: Sporting Adventures in the Northern Seas. New York: Harper \& Brothers. 
Lamont, James. 1876. Yachting in the Arctic Seas; or, Notes of Five Voyages of Sport and Discovery, in the Neighborhood of Spitzbergen and Novaya Zelmlja. London: Chatto and Windus.

Lovelock, Brent. 2008. "An Introduction to Consumptive Wildlife Tourism", in Tourism and the Consumption of Wildlife: Hunting, Shooting and Sport Fishing, edited by Brent Lovelock New York: Routledge.

Maher, Patrick T., Emma J. Stewart and Michael Lück. 2011. Polar Tourism. Human, Environmental and Governance Dimension. New York: Cognizant Communication Corporation.

Nielsen, Jens Petter. 2004. "Ishavet er vår åker", in Norsk Polarhistorie vol. 3, edited by Einar Arne Drivenes, Harald Dag Jølle and Ketil Zachariassen, 477-520. Oslo, Gyldendal.

Reilly, John T. 2009. Greetings from Spitsbergen: Tourists at the Eternal Ice 1827-1914. Trondheim: Tapir Academic Press.

Sillanpää, Pia. 2008. "The Scandinavian Sporting Tour 1830-1914", in Tourism and the Consumption of Wildlife. Hunting, Shooting and Sport Fishing, edited by Brent Lovelock, 5972. New York: Routledge.

Snyder, John. 2007. "Pioners of Polar Tourism and their Legacy". In Prospects of Polar Tourism edited by John Snyder and Bernard Stonehouse. CAB International, Wallingford.

Stonehouse, Bernard \& John Snyder. 2010. Polar tourism: An Environmental Perspective. Bristol: Channel View Publications.

Tosh, John. 2011. "The History of Masculinity: An outdated Consept? " in What is Masculinity? Historical Dynamics from Antquity to the Contemporary World, edited by John H. Arnold \& Sean Brady. London: Palgrave Macmillian.

Viken, Arvid \& Jørgensen, Frigg. 1998. "Tourism in Svalbard", Polar Record 34 (189): 123128.

Wheeler, Sessions S. 1985. Gentleman in the Outdoors: A Portrait of Max C. Fleischmann. Reno, NV: University of Nevada Press.

\section{NOTE}

1 Anatol Heinz received this book as a gift in 1959 and translated Löwenigh's letter into Norwegian. He published the translation in Polarboken 1959/60. 